\title{
Histone H2A Type 1
}

National Cancer Institute

\section{Source}

National Cancer Institute. Histone H2A Type 1. NCI Thesaurus. Code C162908.

Histone H2A type 1 (130 aa, 14 kDa) is encoded by the human H2AC11, H2AC13,

$\mathrm{H} 2 \mathrm{AC} 15, \mathrm{H} 2 \mathrm{AC} 16$ and $\mathrm{H} 2 \mathrm{AC} 17$ genes. This protein plays a role in histone-dependent transcription regulation, DNA repair, DNA replication and chromosomal stability. 